\title{
Risk-based Performance, Nature of Property and Executive's Steady Compensation: Evidence from Chinese Corporations
}

\author{
Danlu $\mathrm{Bu}^{1} \&$ Homayoon Shalchian ${ }^{2}$ \\ ${ }^{1}$ professor of accounting, Department of Accounting, South-western University of Finance and Economics, China \\ 2 professor of finance, Department of Finance and Operations, Laurentian University, Canada \\ Correspondence: Homayoon Shalchian, professor of finance, Department of Finance and Operations, Laurentian \\ University, Canada
}

Received: November 16, 2016

Accepted: December 20, 2016

Online Published: January 10, 2017

doi:10.5430/afr.v6n1p57

URL: http://dx.doi.org/10.5430/afr.v6n1p57

\begin{abstract}
In this paper, we analyze the steadiness of executive compensation relative to the financial performance of Chinese enterprises. We dissociate the firm's operating performance and risk-based performance (changes in firm's fair value) and we examine separately the steadiness of executive compensation relative to each portion of a firm's performance. Our results show that in China, executive compensation is somewhat steady relative to the firm's performance and more particularly to the firm's risk-based performance. Our results also suggest that executive compensation is relatively steadier in the Chinese state-owned enterprises and, more particularly, in the firms controlled by local (provincial) governments.
\end{abstract}

Keywords: Corporate governance, Executive compensation, Risk-based Performance

\section{Introduction}

Executive compensation, and particularly its relation to a firm's performance, has been a popular field of study in finance. Theoretically, it could be expected that separation of management and ownership would result in conflict of interest between risk-averse managers and risk-neutral stockholders (Jensen, 1986; Hubbard, 1998). This conflict could lead to underinvestment of the firm's cash flow (Holmstrong and Weis, 1985; Jensen, 1993). Given that the executive's compensation can constitute an agency problem, several studies suggest that the executive compensation should be, at least to some extent, performance-based. Garvey et al. (1998) analyze the relation between the short-term stock prices and optimal management compensation. Similarly, Hirshleifer and Suh (1992) suggest an "optimal profit-based" mechanism for the executive's compensation. Further, it has been argued that the performance-based compensation system can constitute an incentive for the risk-averse executive to create more value for the shareholders, however, it can also lead to an overinvestment of the firm's cash flow (Bu et al., 2015).

In China, executives benefit from a fixed salary and a performance-based compensation. On the other hand, the Chinese mechanism of executive's compensation can be qualified as "Generous Reward and Gentle Penalty" (Bu et al., 2015). In case of a rise of the firm's performance, the executives obtain additional compensations, and in case of a decline of the firm's performance, they are not subject to severe penalties. This compensation system would create a relative stability of the executive's compensation and a steadiness of the executive's compensation relative to the fluctuations of the firm's performance. Moreover, given the personal benefits of risky investment, managers tend not only to overinvest the firm's cash flow in unprofitable projects (Tang et al., 2010; Bu et al., 2015), but they also proceed frequently to purchases of financial assets and inefficient mergers and acquisitions (Zhang and Guo, 2007; Fang, 2008).

Further, the financial crisis in 2008 drew considerable attention to the fair value of firms in China. During the past decade, changes in fair values have become an important source of profit (loss) for Chinese companies and a factor in the determination of the executives' compensation (Sun and Liu, 2006). By definition, fair value is "the amount at which an asset could be traded (or a liability settled) between knowledgeable and willing parties". As for the profit (loss) due to the changes of fair value, it consists of the difference between the sales price and the initial cost of the asset. Given the uncertainty of the markets in the past decade, changes of fair values are significantly more risky relative to operating profit. In China, executive compensation is, to some extent, performance-based. However, due to the high level of speculation on the financial markets, the relation between executive compensation and risk-based 
performance (changes in fair value) is not clear. The Chinese mechanism of performance-based compensation for executives does not classify the firm's performance based on the associated risk and considers only the total performance. In other words, managers may be encouraged to undertake risky financial transactions instead of improving the operating profit of the firm in order to benefit from the potentially higher changes in fair value and thus consequently, increase their own compensation (Sun and Liu, 2006; Fang, 2008).

In this paper, we analyze the relation between executive compensation and risk-based performance in China. In order to do this, we dissociate total firm performance from operating performance (represented by operating income) and risk-based performance (represented by changes in a firm's fair value). We then analyze separately the steadiness of executive compensation relative to each portion of a firm's performance. We conduct our study using a relatively large number of Chinese companies during the period 2007-2010.

The paper is organized as follows. In the next section, we present the theoretical framework and our hypotheses. Sections 3 and 4 will present respectively the data and our methodology. We present our results and conclusions respectively in sections 5 and 6 .

\section{Theoretical Framework and Hypotheses}

The relation between executive compensation and a firm's financial performance in China has been the subject of numerous studies during the past decade ( $\mathrm{Li}, 2000$; Wei, 2000). Several studies find a positive and significant relation between executive compensation and Chinese firms' performance (Du and Zhuo, 2005; Du and Wang, 2007; Xin et al., 2007; Fang, 2009; Chen and Ding, 2011).

Several studies also find that executive compensation in China is somewhat steady relative to the fluctuation of a firm's financial performance. For instance, Fang $(2009$; 2011) and Xu and Zeng (2010) find a relatively significant increase in positive changes in the fair value of the firm and a relatively slight decrease in the case of negative changes in a firm's value. Similarly, Bu et al. (2015) describe the Chinese executive compensation mechanism as a system that supports a "Generous Reward and Gentle Penalty". Their study shows that Chinese executive compensation increases more significantly following the firm's financial success than it decreases following financial loss. Bu et al. (2015) also argue that in the case of the firm's financial success, the executives take the credit and increase their own compensation. On the other hand, in the case of a financial loss, the executives justify the failure by evoking social and economic factors. Their results show that the Chinese compensation mechanism for executives encourages them to invest in projects without there necessarily being positive NPVs and, consequently, leads often to inefficient investments of a firm's cash flow.

Further, it has been argued that the steadiness of executives' compensation in Chinese state-owned enterprises (SOEs) is, to some extent, caused by SASAC regulations (Bu et al., 2015). (Note 1) For instance, SASAC regulation stipulates that the executives' compensation in SOEs must be partly based on a firm's performance. However, SASAC does not distinguish firms based on their specific financial characteristics. Therefore, SASAC either imposes mandatory distribution of the firm's profit in the form of compensation or it uses economic added value to assess the performance of the executives with a total disregard for the diversity of the activities and sectors of industry. (Note 2) Moreover, SASAC regulations stipulate that in the case of a firm's mediocre financial performance, the executive compensations should be relatively low or even zero but may not be declined (Bu et al., 2015).

Concerning private firms (non-SOEs), executives are in a position to design and to monitor their own compensation. First, it has been argued that Chinese executives have a certain control over the information that is released to the public concerning the firm's financial performance (Lin et al., 1997; Bu et al., 2015). Second, the managerial control over several decisions, including executive compensation, enables managers to increase their own compensation with disregard to the firm's financial success (Wang and Wang, 2007; Fang, 2009). Further, Chen et al. (2005) suggest that due to managerial control and lack of proper supervision, a mediocre performance by Chinese executives may lead to a loss of credibility and social reputation, but not necessarily to a decline in their compensation. Similarly, Lv and Zhao (2008) and Quan et al., (2010) argue that in Chinese non-SOEs, the executives being less accountable relative to those in Chinese SOEs, benefit from a relatively higher steadiness in their compensation. These observations and arguments lead to the following hypotheses:

Hypothesis 1a: The steadiness of executive compensation is higher in Chinese SOEs relative to Chinese non-SOEs.

It has also been suggested that the behavior of the executives in local government-controlled (LDGs) firms is significantly different from central government-controlled (CGCs) firms in China (Xia and Chen. 2007; Pan et al., 2008; Xia et al., 2007; Bu et al., 2015). The executives in LGCs, being relatively less supervised, benefit from 
relatively higher managerial control over their compensation (Xin et al., 2007). These observations and arguments lead to the following hypothesis:

Hypothesis 1b: The steadiness of the executive compensation is higher in Chinese LGCs relative to Chinese CGCs.

Further, financial theory suggests that managers are rational economic agents and therefore risk-averse individuals. This would lead to a conflict of interest between managers and risk-neutral shareholders (Jensen, 1986; Hubbard, 1998; Song and Thakhor, 2006). Theoretically, risk-averse executives should tend to protect their positions by underinvesting and/or ignoring profitable projects in order to maintain their position and compensation (Holmstrong and Weis, 1985). However, in reality, Chinese executives tend to overinvest firms' cash flows in projects with negative NPVs (Xin et al., 2007) and inefficient mergers and acquisitions (Zhang and Guo, 2007). Given the uncertainty on capital markets, trading financial instruments implies a higher potential profit relative to the operating profit, and also higher level of risk. Therefore, Chinese executives may be tempted to undertake relatively more risky operations and attribute the failure to the high risk of the market (Fang, 2009). Hence, in comparison with the operating performance, risk-based performance is more likely to result in a Generous Reward and Gentle Penalty, as suggested by $\mathrm{Bu}$ et al. (2015). These observations and arguments lead to the following hypothesis:

Hypothesis 2a: The steadiness of executive compensation in China is higher relative to risk-based performance than to operating performance.

Finally, given that it has been argued that the executives in local government-controlled firms benefit from a higher level of freedom relative to executives in central government-controlled firms, it would be logical to suppose that $L G C$ executives have a greater tendency to undertake risky financial operations in order to increase their own compensation relative to $C G C$ executives. These observations and arguments lead to the following hypothesis:

Hypothesis 2b: The steadiness of executive compensation relative to risk-based performance is higher in Chinese local government-controlled firms relative to central government-controlled firms.

\section{Data}

We obtain data for executives' compensations from CSMAR database for 1380 Chinese listed companies for the period from 2007 to 2010. (Note 3) We consider firms' net income as an indicator of corporate performance for the same period (Xin et al., 2007; Fang, 2009). Further, we consider several control variables such as the largest shareholder's proportion of stock, the second to tenth largest shareholders' proportion of stock, company size (represented by a firm's total assets) and firms' debt ratios. Table 1 summarizes the description of our variables in this paper: 
Table 1.

\begin{tabular}{|c|c|}
\hline \multicolumn{2}{|c|}{ Dependent variable } \\
\hline LnPay & The natural logarithm of executives' average cash compensation. \\
\hline \multicolumn{2}{|c|}{ Independent variables } \\
\hline $\operatorname{LnNI}$ & The natural logarithm of the firm's net income. \\
\hline$D$ & $\begin{array}{l}\text { Dummy variable that takes the value } 1 \text { when net income declines } \\
\text { and } 0 \text { otherwise. }\end{array}$ \\
\hline Lnprofit & The natural logarithm of the firm's operating profit. \\
\hline$D_{1}$ & $\begin{array}{l}\text { Dummy variable that takes the value } 1 \text { when the operating profit } \\
\text { declines and } 0 \text { otherwise. }\end{array}$ \\
\hline $\operatorname{LnFV}$ & $\begin{array}{l}\text { The natural logarithm of the profit and loss from the changes in } \\
\text { fair value. }\end{array}$ \\
\hline$D_{2}$ & $\begin{array}{l}\text { Dummy variable that takes the value } 1 \text { when the change in fair } \\
\text { value is negative and } 0 \text { otherwise. }\end{array}$ \\
\hline \multicolumn{2}{|c|}{ Control Variables } \\
\hline Board & The size of Board of Directors. \\
\hline Indd & The proportion of independent directors. \\
\hline Dual & $\begin{array}{l}\text { Dummy variable that takes the value } 1 \text { if the chairman and CEO } \\
\text { are the same person, and } 0 \text { otherwise. }\end{array}$ \\
\hline Comi & $\begin{array}{l}\text { Dummy variable that takes the value } 1 \text {, if a remuneration } \\
\text { committee is established within the firm, and } 0 \text { otherwise. }\end{array}$ \\
\hline Lshare & The proportion of shares that the largest shareholder holds. \\
\hline Cbalance & $\begin{array}{l}\text { Checks and balances of the major shareholders (the proportion of } \\
\text { shares that second to tenth largest shareholders hold). }\end{array}$ \\
\hline Clist & $\begin{array}{l}\text { Dummy variable that takes the value } 1 \text {, if the stock is cross-listed, } \\
\text { and } 0 \text { otherwise. }\end{array}$ \\
\hline Lev & Debt ratio $=$ Total debt $/$ Total assets \\
\hline Lnasset & The natural logarithm of corporate size (Total assets). \\
\hline$C G$ & $\begin{array}{l}\text { Dummy variable that takes the value } 1 \text {, if the firm is controlled by } \\
\text { central government, } 0 \text { otherwise. }\end{array}$ \\
\hline Private & $\begin{array}{l}\text { Dummy variable that takes the value } 1 \text {, if the company is a private } \\
\text { firm, } 0 \text { otherwise. }\end{array}$ \\
\hline Central & $\begin{array}{l}\text { Dummy variable that takes the value } 1 \text {, if the firm is registered in } \\
\text { Central part of China, } 0 \text { otherwise. }\end{array}$ \\
\hline West & $\begin{array}{l}\text { Dummy variable that takes the value } 1 \text {, if the firm is registered in } \\
\text { Western part of China, } 0 \text { otherwise. }\end{array}$ \\
\hline
\end{tabular}

\section{Methodology}

Once all information had been gathered, we use a linear regression model (1) to analyze the steadiness of executive's compensation relative to a firm's performance and based on the nature of property:

$$
\begin{aligned}
& \operatorname{LnPay}_{i, t}=\alpha+\beta_{1} \cdot \operatorname{LnNI}_{i, t}+\beta_{2} \cdot D_{i, t}+\beta_{3} \cdot D_{i, t} \cdot \operatorname{LnNI_{itt}}+\beta_{4} \cdot \text { Board }_{i, t}+\beta_{5} \cdot \text { Indd }_{i, t}+\beta_{6} \cdot \text { Dual }_{i, t}+
\end{aligned}
$$

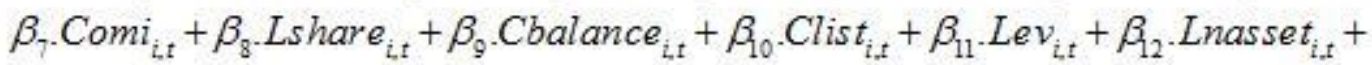

$$
\begin{aligned}
& \beta_{13} \cdot C G_{i, t}+\beta_{14} \text { Private }_{i, t}+\beta_{15} \text {.Central }_{i, t}+\beta_{16} \cdot \text { West }_{i, t}+\beta_{17} \cdot \sum \text { Industry }_{i, t}+\beta_{18} \cdot \sum \text { Year }_{i, t}+\varepsilon_{i, t}
\end{aligned}
$$


The model refers to Fang $(2009 ; 2011)$ with three dummy variables. When net income drops, $D_{i, t}$ takes the value 1 , otherwise 0 . We introduce the variable $D_{i, t}$. LnNI. If the coefficient of the variable is negative, it indicates the existence of the steadiness of the executive compensation relative to the firm's performance. Board represents the size of the board (number of executives). $C G$ is a dummy variable that takes the value 1 when the company is controlled by central government, otherwise 0 . Private is a dummy variable taking the value 1 when the firm is controlled by individuals, otherwise 0. Lshare represents the largest proportion of shares held by the major shareholder. Cbalance is the ratio of the second major shareholder. Clist represents the Cross-listing and takes the value 1 when the company issues B-shares or $\mathrm{H}$-shares simultaneously, otherwise 0 . Dual is a dummy variable that takes 1 when the Chairman and CEO is the same person, otherwise 0 . Indd represents the proportion of independent directors on the board and Comi is a dummy variable that takes 1 when the board sets up a compensation committee, otherwise 0. Lnassets is the size of the firm, represented by the natural logarithm of the firm's total assets and Lev is the firm's leverage, represented by total debt divided by total assets. The geographic factor is captured by "Central" and "West" that take the value 1 when the firms are located respectively in central or western China, and 0 otherwise. We also control for Industry and Year as in Fama and French (1997). In order to analyze the steadiness of executive compensation relative to the operating and risk-based performance, we calculate respectively $\beta_{1} /\left(\beta_{1}+\beta_{3}\right)$ and $\beta_{4} /\left(\beta_{4}+\beta_{6}\right)$. If $\beta_{1} /\left(\beta_{1}+\beta_{3}\right)<\beta_{4} /\left(\beta_{4}+\beta_{6}\right)$. Hypothesis $2 \mathrm{a}$ is thus verified.

Further, we analyze the steadiness of executive compensation relative to the Operating profit. Therefore, we run the regression model (2):

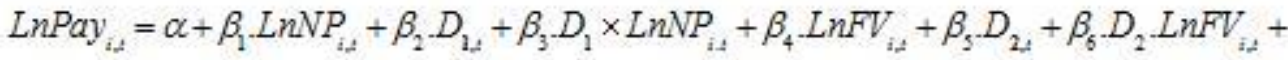

$$
\begin{aligned}
& \beta_{7} \text { Board }_{i,}+\beta_{s} \text {.Indd }_{i, t}+\beta_{9} \text {.Dual }_{i, 2}+\beta_{10} \text { Comi }_{i, 4}+\beta_{11} \text { Lshare }_{i,}+\beta_{12} \text { Cbalance }_{i, 2}+ \\
& \beta_{13} \text {. Clist }_{i, \pm}+\beta_{14} \text { Lev }_{i, t}+\beta_{15} \text {. Lnasset }_{i, \pm}+\beta_{16} \cdot C G_{i, t}+\beta_{17} \text {.Private }_{i, t}+\beta_{18} \text { Central }_{i, 2}+ \\
& \beta_{19} \text { West }_{i, 4}+\beta_{20} \cdot \sum \text { Industry }_{i, 4}+\beta_{21} \cdot \sum \text { Year }_{i, 4}+\varepsilon_{i, 4}
\end{aligned}
$$

Where $L n N P_{i, t}$ represents the natural logarithm of operating profit and $L n F V_{i, t}$ represents the natural logarithm of profit and loss from the change of the fair value. The control variables are the same as in model (1).

To summarize, we perform regressions on our sampled firms through the following steps:

1. We perform the regression model (1) on our full-sample companies in order to analyze the steadiness of the executive compensation (LnPay) relative to the firm's performance represented by net income (LnNI).

2. Further, we divide our sample into state-owned (SOEs) and non-state-owned (non-SOEs) enterprises and we run the regression model (1) on our subsamples in order to analyze the steadiness of the executive compensation relative to the firm's financial performance in each category of firm and based on the type of ownership.

3. We re-run the regression model (1) subdividing our sample into central government-controlled $(C G C s)$ and local government-controlled ( $L G C s)$ enterprises and we run the regression model (1) on our subsamples in order to analyze the steadiness of the executive compensation relative to the firm's financial performance in each category of firm and based on the type of control.

4. We dissociate the operating performance (Operating income) and risk-based performance (Changes in the fair value). Then we run the regression model (2) on our Full-sample as well as our subsamples in order to analyze the steadiness of the executive compensation relative to each portion of the firm's performance.

\section{Empirical Results}

Table 2 summarizes the descriptive statistics for our sampled firms for the 2007-2010 period. The results show that the average executive compensation of 364200 RMBs, a maximum of 1849800 RMBs and a minimum of 44900 RMBs. During the same period, the average net income is 635 million RMBs while the average operating income and the gain (loss) from the changes of fair value are respectively 714 and 3.44 million RMBs. The gains (losses) from the changes of fair value are $0.48 \%$. This result indicates that the gain (loss) from the changes of fair value is not an important source of corporate profit. We also note that approximately $47 \%$ of our sampled firms show losses from the change of fair value. We also note that $37 \%$ hire independent directors and approximately $85 \%$ implement a policy of separate Chairman and CEOs. Finally, $92 \%$ of our sampled firms opted for compensation committees and approximately $29 \%$ of our sampled firms are located in Central and Western parts of China. 
Table 2. Descriptive statistics

\begin{tabular}{|c|c|c|c|c|c|c|}
\hline Variables & $\mathrm{N}$ & Mean & Median & Min & Max & SD \\
\hline$P_{\text {(yuan) }}$ & 1380 & 364200 & 278200 & 44900 & 1849800 & 30.64 \\
\hline$N I$ (million yuan) & 1380 & 635 & 131 & 3.6188 & 11600 & 160000 \\
\hline$D$ & 1380 & 0.29 & 0 & 0 & 1 & 0.46 \\
\hline Profit (million yuan) & 1380 & 714 & 143 & 2.1739 & 12500 & 181000 \\
\hline$D_{1}$ & 1380 & 0.31 & 0 & 0 & 1 & 0.46 \\
\hline$F V_{\text {(million yuan) }}$ & 1380 & 3.44 & 0.013 & -13 & 283 & 4300 \\
\hline$D_{2}$ & 1380 & 0.47 & 0 & 0 & 1 & 0.50 \\
\hline Board & 1380 & 9.27 & 9 & 5 & 15 & 1.91 \\
\hline Indd & 1380 & 0.37 & 0.33 & 0.27 & 0.57 & 0.05 \\
\hline Dual & 1380 & 0.15 & 0 & 0 & 1 & 0.36 \\
\hline Comi & 1380 & 0.97 & 1 & 0 & 1 & 0.16 \\
\hline Lshare & 1380 & 36.84 & 35.04 & 9.23 & 75.84 & 15.48 \\
\hline Cbalance & 1380 & 0.65 & 0.46 & 0.03 & 2.57 & 0.57 \\
\hline Clist & 1380 & 0.14 & 0 & 0 & 1 & 0.34 \\
\hline Lev & 1380 & 20.20 & 19.70 & 0 & 60.50 & 14.67 \\
\hline Asset (million yuan) & 1380 & 15600 & 3110 & 360 & 252000 & 5530000 \\
\hline$C G$ & 1380 & 0.18 & 0 & 0 & 1 & 0.39 \\
\hline Private & 1380 & 0.39 & 0 & 0 & 1 & 0.49 \\
\hline Central & 1380 & 0.17 & 0 & 0 & 1 & 0.38 \\
\hline West & 1380 & 0.13 & 0 & 0 & 1 & 0.33 \\
\hline
\end{tabular}

Table 3 presents the coefficients of correlation between our variables. The results show a positive and significant correlation between executive compensation and corporate performance. However, after separating operating and risk-based performances, we note a positive and significant correlation between executive compensation and operating performance but a relatively weak correlation between executive compensation and risk-based performance. Our results show that most firms have established a performance-based incentive mechanism. However, the compensation based on risk-based performance needs further revisions. 
Table 3. Correlation coefficient matrix

\begin{tabular}{llllllll}
\hline & LnPay & LnNI & $D$ & Lnprofit & $D_{1}$ & LnFV & $D_{2}$ \\
\hline LnPay & 1.0000 & $0.59^{* * *}$ & -0.06 & $0.57^{* * *}$ & -0.03 & 0.04 & -0.01 \\
LnNI & $0.58^{* * *}$ & 1.00 & $-0.23^{* * *}$ & $0.97 * * *$ & $-0.20^{* * *}$ & 0.08 & -0.04 \\
$D$ & -0.07 & $-0.23^{* * *}$ & 1.00 & $-0.21^{* * *}$ & $0.72^{* * *}$ & $-0.18^{* * *}$ & $0.16^{* * *}$ \\
& & & & & & \\
Lnprofit & $0.57^{* * *}$ & $0.96^{* * *}$ & $-0.21^{* * *}$ & 1.00 & $-0.22^{* * *}$ & 0.03 & -0.01 \\
$D_{1}$ & -0.03 & $-0.20^{* * *}$ & $0.72^{* * *}$ & $-0.22^{* * * *}$ & 1.00 & $-0.11^{* * *}$ & $0.11^{* * *}$ \\
LnFV & 0.02 & 0.06 & $-0.17^{* * *}$ & 0.00 & $-0.11^{* * *}$ & 1.00 & $-0.86^{* * * *}$ \\
$D_{2}$ & -0.00 & -0.05 & $0.16^{* * *}$ & 0.001 & $0.11^{* * * *}$ & $-0.98^{* * *}$ & 1.00 \\
\hline
\end{tabular}

Note: The lower left part of is the Pearson test, and the upper right part is the Spearman test. ${ }^{*},{ }^{* *}$ and ${ }^{* * *}$ denote $10 \%$, $5 \%$ and $1 \%$ level of significance.

Table 4 presents the results of the regression model (1) on full-sample firms and subsamples. First, we note that factor loading on $L n N I$ is positive and statistically significant for full-sample and all subsamples. The coefficients are respectively 0.19 and 0.22 for full-sample and SOEs and $t$-statistic reveals that they are significant at $1 \%$ level. Column (2) presents the results of the steadiness of executive compensation. Our results suggest that factor loading on $D^{*} L n N I$ is negative and statistically significant at $5 \%$ level. These results suggest that executive compensation is less sensitive to the decline in a firm's performance. On the other hand, our results suggest that the marginal level of the rise in executive compensation has a positive relation of 1.20 with the rise of corporate performance. (Note 4) This result suggests that the executive compensation rise following a rise in corporate performance is 1.20 times higher than the decline of executive compensation following a decline of corporate performance. Overall, our results suggest that executive compensation and corporate performance have a positive and significant relation. However, the increase in executive compensation seems relatively more sensitive to the rise of corporate performance while its decrease seems relatively less sensitive to the decline of corporate performance.

Columns (3), (4), (5) and (6) in table 4 present, respectively, the results of regression model (1) on SOEs and non-SOEs, CGC and LGC firms. Our sample consists of 834 SOEs, 545 non-SOEs. Among 834 SOEs, 255 firms are under Central government control and 579 are under local government's control. Our results show that executive compensation is steady in SOEs and its sensitivity to the rise of corporate performance is 1.29. (Note 5) The factor loading on $D^{*} L n N I$ is negative and significant at $1 \%$ level which indicates that executive compensation is relatively less sensitive to the decline of corporate performance. Our results also suggest that executive compensation in non-SOEs is not significantly sensitive to corporate performance.

Finally, our results show that executive compensation is steady in $L G C$ firms. The factor loading on $D^{*} L n N I$ show a coefficient of -0.05 and t-statistic reveals that the result is significant at $10 \%$ level. We calculate the sensitivity of the marginal increase of executive compensation to the rise of corporate performance at 1.27. (Note 6) Our results also suggest that executive compensation in $C G C$ does not show any significant steadiness. Our results suggest that executive compensation is relatively steadier in SOEs and less steady in non-SOEs. Our results therefore, indicate that compensation contracts are less efficient in SOEs relative to non-SOEs. 
Table 4. The regression results of executive pay and corporate performance

\begin{tabular}{|c|c|c|c|c|c|c|}
\hline Variable & $\begin{array}{l}\text { Full sample } \\
\mathrm{N}=1379\end{array}$ & $\begin{array}{l}\text { Full sample } \\
\mathrm{N}=1379\end{array}$ & $\begin{array}{l}\text { State-owned } \\
\mathrm{N}=834\end{array}$ & $\begin{array}{l}\text { Private } \\
\mathrm{N}=545\end{array}$ & $\begin{array}{l}\text { CGC } \\
\mathrm{N}=255\end{array}$ & $\begin{array}{l}\text { LGC } \\
\mathrm{N}=579\end{array}$ \\
\hline \multirow{2}{*}{ Constant } & $6.41 * * *$ & $6.31 * * *$ & $6.75^{* * *}$ & $4.62 * * *$ & $9.80 * * *$ & $5.73^{* * * *}$ \\
\hline & (18.24) & $(17.31)$ & (15.41) & $(7.44)$ & (12.15) & $(9.94)$ \\
\hline \multirow{2}{*}{$L n N I$} & $0.19 * * *$ & $0.21 * * *$ & $0.22 * * *$ & $0.20 * * *$ & $0.14 * * *$ & $0.24 * * *$ \\
\hline & $(10.21)$ & (9.99) & $(8.25)$ & (5.87) & $(3.03)$ & (7.16) \\
\hline \multirow{2}{*}{$D$} & & $0.46 * *$ & $1.05^{* * *}$ & -0.46 & 1.14 & $1.09 * *$ \\
\hline & & $(2.23)$ & $(3.35)$ & $(-0.70)$ & $(1.43)$ & (1.97) \\
\hline \multirow{2}{*}{$D * L n N I$} & & $-0.02 * *$ & $-0.05 * * *$ & 0.03 & -0.06 & $-0.05^{*}$ \\
\hline & & $(-2.01)$ & $(-3.07)$ & $(0.81)$ & $(-1.38)$ & $(-1.87)$ \\
\hline \multirow{2}{*}{ Board } & 0.01 & 0.01 & -0.01 & $0.05 * * *$ & $-0.06 * * *$ & -0.07 \\
\hline & (1.04) & $(0.98)$ & $(-1.20)$ & $(3.59)$ & $(-3.16)$ & $(-0.48)$ \\
\hline \multirow{2}{*}{ Indd } & 0.37 & 0.37 & -0.30 & $2.31 * * *$ & $-2.32 * * *$ & 0.30 \\
\hline & $(1.22)$ & $(1.21)$ & $(-0.82)$ & (4.34) & $(-3.82)$ & $(0.65)$ \\
\hline \multirow{2}{*}{ Dual } & 0.01 & 0.02 & $-0.11 *$ & $0.13 * *$ & $0.23^{*}$ & $-0.16^{* *}$ \\
\hline & $(0.26)$ & $(0.35)$ & $(-1.66)$ & $(2.29)$ & $(1.75)$ & $(-2.19)$ \\
\hline \multirow{2}{*}{ Comi } & 0.11 & 0.12 & $0.24^{*}$ & -0.17 & -0.02 & $0.40 * *$ \\
\hline & $(1.13)$ & $(1.24)$ & (1.64) & $(-1.38)$ & $(-0.08)$ & $(2.41)$ \\
\hline \multirow{2}{*}{ Lshare } & $-0.003 * *$ & $-0.003 * *$ & $-0.004 * *$ & 0.001 & -0.004 & $-0.004 *$ \\
\hline & $(-2.20)$ & $(-2.20)$ & $(-2.22)$ & $(0.47)$ & $(-1.14)$ & $(-1.80)$ \\
\hline \multirow{2}{*}{ Cbalance } & 0.04 & 0.04 & 0.06 & 0.06 & 0.12 & 0.01 \\
\hline & (1.07) & (1.07) & (1.38) & $(1.00)$ & $(1.45)$ & $(1.26)$ \\
\hline \multirow{2}{*}{ Clist } & 0.07 & 0.07 & $0.11 *$ & -0.13 & $0.29 * * *$ & 0.10 \\
\hline & $(1.29)$ & $(1.34)$ & $(1.83)$ & $(-1.10)$ & $(2.89)$ & $(1.29)$ \\
\hline \multirow{2}{*}{ Lev } & $-0.002 * *$ & $-0.002 * *$ & 0.000 & $-0.009 * * *$ & 0.001 & 0.000 \\
\hline & $(-2.27)$ & $(-2.14)$ & $(0.13)$ & $(-4.91)$ & $(0.34)$ & $(0.03)$ \\
\hline \multirow{2}{*}{ Lnasset } & $0.09 * * *$ & $0.08 * * *$ & $0.06^{*}$ & $0.15^{* * *}$ & 0.08 & 0.06 \\
\hline & $(3.64)$ & $(3.00)$ & $(1.82)$ & $(3.41)$ & (1.39) & (1.57) \\
\hline \multirow{2}{*}{$C G$} & 0.08 & 0.07 & & & & \\
\hline & (1.58) & $(1.53)$ & & & & \\
\hline \multirow{2}{*}{ Private } & 0.01 & 0.01 & & & & \\
\hline & $(0.30)$ & $(0.15)$ & & & & \\
\hline \multirow{2}{*}{ Central } & $-0.24 * * *$ & $-0.23 * * *$ & $-0.27 * * *$ & $-0.25 * * *$ & $-0.35 * * *$ & $-0.26 * * *$ \\
\hline & $(-5.47)$ & $(-5.39)$ & $(-5.32)$ & $(-3.37)$ & $(-3.12)$ & $(-4.35)$ \\
\hline \multirow{2}{*}{ West } & $-0.38 * * *$ & $-0.37 * * *$ & $-0.47 * * *$ & -0.03 & $-0.27 * * *$ & $-0.51 * * *$ \\
\hline & $(-7.70)$ & $(-7.65)$ & $(-7.96)$ & $(-0.32)$ & $(-2.42)$ & $(-6.80)$ \\
\hline Industry & Control & Control & Control & Control & Control & Control \\
\hline Year & Control & Control & Control & Control & Control & Control \\
\hline $\operatorname{Adj} R^{2}$ & 0.46 & 0.46 & 0.54 & 0.43 & 0.58 & 0.52 \\
\hline
\end{tabular}

${ }^{*},{ }^{* *}$ and ${ }^{* * *}$ denote $10 \%, 5 \%$ and $1 \%$ level of significance. 
Further, we break down firms' financial performance into operating and investment performances (operating income and changes in fair value) and we analyze the steadiness of the executive compensation relative to each portion of risk-based performance. The factor loading on $L n F V$ and $D_{2} L n F V$ show respective coefficients of 0.02 and 0.04 and $\mathrm{t}$-statistics reveal that coefficients are significant at the 5\% level. The difference between the two coefficients $(-0.02)$ shows that declines in risk-based performance do not necessarily result in a decline of executive compensation. This is due to the fact that the performance-based losses can be covered by operational profits. This result could confirm those of Bu et al. (2015) who suggest a steadiness of executive compensation in China which may lead to corporate overinvestment.

Finally, we subdivide SOEs into Central government-controlled (CGC) and Local government-controlled (LGC) firms and run regression model (2). Factor loading on $D_{2} L n F V$ shows that, in both types of firm, executive compensation shows a relatively low sensitivity to the risk-based performance. The coefficients for LGCs are negative and significant at the $5 \%$ level.

Table 5. Regression results of different risk-based performance and executive pay

\begin{tabular}{|c|c|c|c|c|}
\hline Variables & State-owned & $\mathrm{N}=834$ & $\begin{array}{l}\text { Central holding } \\
\mathrm{N}=255\end{array}$ & $\begin{array}{l}\text { Local holding } \\
\mathrm{N}=579\end{array}$ \\
\hline Constant & $\begin{array}{l}6.99 * * * \\
(15.46)\end{array}$ & & $\begin{array}{l}9.65^{* * * *} \\
(11.58)\end{array}$ & $\begin{array}{l}6.26^{* * * *} \\
(10.38)\end{array}$ \\
\hline Lnprofit & $\begin{array}{l}0.18^{* * * *} \\
(7.38)\end{array}$ & & $\begin{array}{l}0.13 * * * \\
(2.96)\end{array}$ & $\begin{array}{l}0.19 * * * \\
(6.14)\end{array}$ \\
\hline$D_{1}$ & $\begin{array}{l}0.53 \\
(1.27)\end{array}$ & & $\begin{array}{l}1.01 \\
(1.41)\end{array}$ & $\begin{array}{l}0.25 \\
(0.47)\end{array}$ \\
\hline$D_{1} *$ Lnprofit & $\begin{array}{l}-0.02 \\
(-0.96)\end{array}$ & & $\begin{array}{l}-0.05 \\
(-1.30)\end{array}$ & $\begin{array}{l}-0.01 \\
(-0.18)\end{array}$ \\
\hline$L n F V$ & $\begin{array}{l}0.02 * * \\
(2.36)\end{array}$ & & $\begin{array}{l}0.03 \\
(1.27)\end{array}$ & $\begin{array}{l}0.02 * \\
(1.64)\end{array}$ \\
\hline$D_{2}$ & $\begin{array}{l}0.15 \\
(0.75)\end{array}$ & & $\begin{array}{l}0.30 \\
(0.79)\end{array}$ & $\begin{array}{l}-0.01 \\
(-0.03)\end{array}$ \\
\hline$D_{2} * L n F V$ & $\begin{array}{l}-0.04 * * \\
(-2.42)\end{array}$ & & $\begin{array}{l}-0.03 \\
(-1.01)\end{array}$ & $\begin{array}{l}-0.04 * * \\
(-2.25)\end{array}$ \\
\hline Board & $\begin{array}{l}-0.01 \\
(-0.93)\end{array}$ & & $\begin{array}{l}-0.06 * * * \\
(-3.01)\end{array}$ & $\begin{array}{l}-0.00 \\
(-0.06)\end{array}$ \\
\hline Indd & $\begin{array}{l}-0.30 \\
(-0.82)\end{array}$ & & $\begin{array}{l}-2.36 * * * \\
(-3.82)\end{array}$ & $\begin{array}{l}0.33 \\
(0.73)\end{array}$ \\
\hline Dual & $\begin{array}{l}-0.11^{*} \\
(-1.78)\end{array}$ & & $\begin{array}{l}0.23^{*} \\
(1.71)\end{array}$ & $\begin{array}{l}-0.16^{* *} \\
(-2.26)\end{array}$ \\
\hline Comi & $\begin{array}{l}0.22 \\
(1.53)\end{array}$ & & $\begin{array}{l}-0.03 \\
(-0.11)\end{array}$ & $\begin{array}{l}0.36 * * \\
(1.48)\end{array}$ \\
\hline Lshare & $\begin{array}{l}-0.003 * \\
(-1.94)\end{array}$ & & $\begin{array}{l}-0.004 \\
(-1.12)\end{array}$ & $\begin{array}{l}-0.003 \\
(-1.50)\end{array}$ \\
\hline Cbalance & $\begin{array}{l}0.07 \\
(1.58)\end{array}$ & & $\begin{array}{l}0.11 \\
(1.34)\end{array}$ & $\begin{array}{l}0.03 \\
(0.58)\end{array}$ \\
\hline Clist & $\begin{array}{l}0.10 \\
(1.72)\end{array}$ & & $\begin{array}{l}0.26 * * \\
(2.48)\end{array}$ & $\begin{array}{l}0.10 \\
(1.36)\end{array}$ \\
\hline Lev & $\begin{array}{l}0.00 \\
(0.28)\end{array}$ & & $\begin{array}{l}0.00 \\
(0.08)\end{array}$ & $\begin{array}{l}0.00 \\
(0.34)\end{array}$ \\
\hline Lnasset & $\begin{array}{l}0.06^{*} \\
(1.89)\end{array}$ & & $\begin{array}{l}0.07 \\
(1.35)\end{array}$ & $\begin{array}{l}0.07^{*} \\
(1.67)\end{array}$ \\
\hline Central & $\begin{array}{l}-0.27 * * * \\
(-5.34)\end{array}$ & & $\begin{array}{l}-0.37 * * * \\
(-3.24)\end{array}$ & $\begin{array}{l}-0.26 * * * \\
(-4.40)\end{array}$ \\
\hline West & $\begin{array}{l}-0.47 * * * \\
(-8.00)\end{array}$ & & $\begin{array}{l}-0.25 * * \\
(-2.14)\end{array}$ & $\begin{array}{l}-0.53 * * * \\
(-6.79)\end{array}$ \\
\hline Industry Year & Control & & Control & Control \\
\hline $\operatorname{Adj} R^{2}$ & 0.54 & & 0.58 & 0.52 \\
\hline
\end{tabular}




\section{Conclusions}

In this paper, we consider 1380 firms that have experienced gains or losses from the changes of fair value during the period 2007-2010. Analyzing executive compensation and corporate performance, we find a positive and significant relation between the two variables, indicating that compensation contracts are, to some extent, based on firms' performance.

Our results also indicate some steadiness in executive compensation. More specifically, the executive compensation in state-owned enterprises shows a significant steadiness. Further, our results show that executive compensation seems to be steadier in local government-controlled firms relative to central government controlled firms. Overall, our results confirm those of Bu et al. (2015) who suggest a Generous Reward and Gentle Penalty for the executives of SOES in China. Further, our results suggest a lower steadiness in executive compensation in Chinese non-SOEs

Our study also suggests that executive compensation is steadier relative to risk-based performance and less steady relative to operating performance. Moreover, we find that there is more significant steadiness in executive compensation for risk-based performance in local government controlled enterprises relative to central government-controlled enterprises. Therefore, the executives in LGCs receive relatively high compensation from their investment decisions while they undergo a relatively lower penalty in case of a decline of risk-based performance. In other words, in Chinese SOEs and more particularly in Chinese LGCs, executive compensation does not show a significant sensitivity to the changes in fair value of the firm. This could encourage the Chinese executives to be risk-prone. Finally, our results suggest that it would be worthwhile to revise the compensation contracts for executives in China. For example, it would be plausible to design contracts which would encourage the executives to concentrate more effort on improving operating performance rather than risk-based performance and consequently, avoid the tendency to overinvest the firm's cash flow.

\section{References}

Bu, D., Shalchian, H. \& Zhang, C. (2015). Steady Compensation, Overconfident Executives and Overinvestment. International Research Journal of Applied Finance, 465-478.

Chen D.H , Chen, X. Y. \& Wan, H. L. (2005). Regulation and Non-pecuniary Compensation in Chinese SOEs. Economic Research Journal, 2, 92-101.(in Chinese)

Chen, Z. \& Ding, Z. M. (2011). A Study on Executive Compensation of Monopoly Industry Based on Managerial Power Approach. China Industrial Economics, 9,119-129.

Du, S.L. \& Zhuo, Y. L. (2005). Empirical Study on the Determination of CEO's Compensation-Based on Chinese Listed Companies. Management World, 8, 114-120.

Du, X.Q. \& Wang, L. H. (2007). Empirical Research on Correlation between Compensation Schemes of Management and the Change of Performance of Public Listed Companies. Accounting Research, 1, 58-65.

Fang, J.X. (2008). The Government Intervention, the Nature of Ownership and Enterprises Mergers \& Acquisitions. Management World, 9, 118-124.

Fang, J.X. (2009). Is Top Management Compensation of Chinese Public Companies Sticky? Economic Research Journal, 3, 110-124.

Fang, J.X. (2011). Managerial Power and Asymmetry of Compensation Change in China's Public Companies. Economic Research Journal, 4, 107-120.

Garvey, G. T., Grant, S. \& King, S. P. (1998). Talking down the firm: Short-term market manipulation and optimal management compensation. International Journal of Industrial Organization, 16, 555-570. https://doi.org/10.1016/S0167-7187(97)00016-7

Hirshleifer, D., \& Suh, Y. (1992). Risk, managerial effort and project choice. Journal of Financial Intermediation, 2 , 308-345. https://doi.org/10.1016/1042-9573(92)90004-W

Holmstrom, B., \& Weiss, L. (1985). Managerial incentives, investment and aggregate implications. Review of Economic Studies, 52, 403-26. https://doi.org/10.2307/2297661

Hubbard, R. G. (1998). Capital-market Imperfections and Investment. Journal of Economic Literature, 36, 193-225.

Jensen, M. C. (1986). Agency Costs of Free Cash Flow, Corporate Finance and the Market Takeovers. American Economic Review, 76, 323-329. 
Jensen, M. C. (1993). The Modern Industrial Revolution, Exit, and Failure of Internal Control System. Journal of Finance, 48(3), 831-880. https://doi.org/10.1111/j.1540-6261.1993.tb04022.x

Lv, C.J. \& Zhao, Y. H. (2008). A Study on the Effect of the Incentive Given to Managers of SOEs. Management World, 11, 99-109.

Pan, H.B., Xia, X. P. \& Yu, M. G. (2008). Government Intervention, Political Connections and the Mergers of Local Government-Controlled Enterprises. Economic Research Journal, 4, 41-52.

Quan, X.F., Wu S. N. \& Wen, F. (2010). Managerial Power, Private Income and Compensation Rigging. Economic Research Journal, 11, 73-86.

Song, F. \& Thakhor, A. V. (2006). Information Control, Career Concerns, and Corporate Governance. Journal of Finance, 61(4), 1845-1896. https://doi.org/10.1111/j.1540-6261.2006.00891.x

Sun, Z. \& Liu, H. (2006). The Review of Positive on Accounting Standards and The Prospect The New Position of Chinese"

Tang, X.S., Zhou, X. S. \& Ma, R. J. (2010). Government Intervention, GDP Growth and Local SOE Overinvestment. Journal of Financial Research, 8, 33-48.

Wang, K.M., Wang, Z.C. (2007). Executive Control, Compensation and Earnings Management-- Based on Empirical Studies of Chinese Listed Companies. Management World, 7, 111-119.

Xia, J.J. \& Zhang, Y. (2008). The Conflicts between Control Rights and Incentives: An Empirical Analysis on the Effect of Stock Incentive in China. Economic Research Journal, 3, 87-98.

Xin, Q.Q., Lin, B. \& Wang, Y. C. (2007). Government Control, Executive Compensation and Capital Investment. Economic Research Journal, 8, 110-122.

Xu, J.C. \& Zeng, X. Y. (2010). The CEOs Compensation Contract and Fair Value Accounting in China. Accounting Research, 3, 12-19.

Zhang, M. \& Guo, S. Y. (2007). Executive Compensation Drives Merger and Acquisition: Evidence from Listed Companies in China. Journal of Finance and Economics, 12, 103-113.

\section{Notes}

Note 1. State-owned Asset Supervision and Administration Council (SASAC) is a Chinese government agency responsible for supervision and reporting on state-owned assets and enterprises.

Note 2. SASAC publications $(2004,2010)$

Note 3. China Stock Market and Accounting Research (CSMAR)/ Research database is produced jointly by GTA Information Technology Co. LTD and the University of Hong Kong and provides reports on Chinese listed companies to meet the needs for Chinese economic analysis and research.

Note 4. The sensitivity of the marginal increase of executive compensation to corporate performance is calculated as: $0.2110 /(0.2110-0.0203)$.

Note 5. The sensitivity of marginal increases of executive compensation to corporate performance is calculated as: $0.2151 /(0.2151-0.0488)$.

Note 6. The sensitivity of the marginal increase of executive compensation to corporate performance is calculated as: $0.2357 /(0.2357-0.0495)$. 